\title{
地空を利用した夜間自然換気による潜熱蓄熱材の蓄冷効果に関する研究 STUDY ON COLD STORAGE OF PHASE CHANGE MATERIAL ON THE FLOOR OF A HOUSE WITH NIGHT NATURAL VENTILATION
}

\author{
李 泰 徹*1, 佐藤理 ${ }^{* 2}$, 浅輪貴史 ${ }^{* 3}$, 河合英徳 ${ }^{* 4}$, \\ 平山由佳理 ${ }^{2}$, 太田 勇 ${ }^{* 2}$, 佐藤友紀 ${ }^{* 5}$, 林 禎彦*6 \\ Taecheol LEE, Rihito SATO, Takashi ASAWA, \\ Hidenori KAWAI, Yukari HIRAYAMA, Isamu OHTA, \\ Yuki SATO and Yoshihiko HAYASHI
}

\begin{abstract}
In this paper, we focus on introduction of phase change material into a house for secure a cold storage with night natural ventilation. Measurement was mainly conducted for a room of the house where it has two openings at floor level. We measured vertical air temperature distribution and inflow wind speed to understand indoor thermal characteristics. And heat flow was also measured on the floor and under the floor to reveal cold storage mechanism. Vertical air temperature distribution of indoor was influenced by inflow wind speed and air temperature difference between indoor and outdoor. Cold storage tended to be proportional to air temperature difference between indoor and outdoor. Cold storage accelerated as the condition of high air temperature difference between indoor and outdoor and low inflow wind speed because cold air accumulated along the floor not to be mixed upper air of the indoor space.
\end{abstract}

Keywords : Night natural ventilation, Phase change material, Vertical air temperature distribution, Cold storage 夜間自然換気，相変化物質，上下温度分布，蓄冷

\section{1. はじめに}

建物の自然換気・通風に関する既往の研究は, 中間期から夏季にお ける日中の熱的快適性や空気質の向上及び省エネルギー効果に着目 したものが多くなされている. 自然換気・通風による効果を定量的に 評価するためには, 換気量を精度良く測定・予測する必要があること から, 自然換気・通風時の風圧係数, 換気量に関寸る知見については多 くの蓄積がある ${ }^{1-7)}$ 。一方, 夜間自然換気については, 低温な外気を室 内に取入れることで建物内部に滞留した熱の排気, 躯体蓄冷による日 中の泠房負荷削減に寄与できることから,オフィスなどでは躯体熱容 量が大きいことを活かしたナイトパージによる躯体蓄冷の事例も多 ( $^{8-9)}$. また, 海外においても夜間換気の効率は換気量, 建物熱容量に 大きく依存するといった研究結果が多い 10-13)。しかしながら, 日本の 戸建住宅の大部分を占める熱容量が小さい木造住宅においては, 利用 事例や研究の蓄積が少なく,また大風量の換気設備や開口部を制御す るといった事例がこれまで少なかったこともあり,夜間換気に関する 知見の蓄積は十分とはいえない。近年, 住宅への IoT(Internet of Things)導入が進む中で, オフィスと同様に自然換気の自動化もみら れるようになり,夜間においても外気象条件に応じた適切な空開閉を 行うことで自然換気時間が増えると予想される.また，省エネルギー と熱中症対策を両立できる環境技術としても夜間換気は重要である。
今後, 夜間換気をより効果的に利用するためには, 部位ごとに適切な 熱容量の建材を導入していく蓄冷技術と合わせて活用することが有 用である。その一つとして, 軽量で高密度に蓄冷できる潜熱蓄熱部材 (Phase Change Material, PCM)は小熱容量の木造住宅にも応用可能 と考えられる.これまで冬季の PCM の蓄熱については研究が進めら れているが 14-15)蓄冷効果に関寸る研究は少ない.

夜間自然換気による蓄冷効果を明らかにする上では, その材料自体 の熱容量に加えて低温な外気を室内に取り入れることで形成される 上下温度分布の影響を把握することが重要である.これまでもオフィ スを対象とした事例では大空間の上下温度分布に関する測定や数值 解析の研究 16-18) が幾つかなされているが, 住宅に関する検討事例は少 ない. 室内の各部位別の蓄冷量の推定に効果的な上下温度分布の特性 を明らかにすることは, 地域別の異なる気象条件に適合する開口率や 建材の種類・設置部位選定などの環境設計に有用であると考えられる. そこで本研究では, 建物蓄冷に有効と考えられる潜熱蓄熱材に着目 し, 地空を用いて夜間自然換気を実施する際, 各気象条件で形成され る室内上下温度分布特性を把握した上で, 室内床に敷設した PCM の 蓄冷量を定量的に分析し,夜間自然換気時の蓄冷効果を明らかにする ことを目的とする.

\footnotetext{
*1 東京工業大学大学院 大学院生 · 修士 (工学)

*2 ミサワホーム総合研究所 博士 (工学)

*3 東京工業大学大学院 准教授・博士 (工学)

*4 東京工業大学大学院 助教 $\cdot$ 博士 (工学)

*5 大建工業総合開発研究所 博士 (学術)

*6 大建工業総合開発研究所
}

Grad. Student, Tokyo Institute of Technology, M.Eng. Misawa Homes Institute of Research and Development, Dr.Eng. Assoc. Prof., Tokyo Institute of Technology, Dr.Eng. Assist. Prof., Tokyo Institute of Technology, Dr.Eng. Daiken Co., R\&D Center, Ph.D Daiken Co., R\&D Center 


\section{2. 既往研究の整理に基づく夜間自然換気の分析方針}

\section{1 本研究で着目するパラメータ}

夜間自然換気を実施する際, 換気の駆動力となる屋内外気温差及び 流入風速の度合いによって室内に形成される気流・気温の性状は異な る。迫ら ${ }^{19}$ は屋内外気温差と流入風速には強い相関があり, 屋内外 気温差が大きいほど流入風速が早くなる傾向を示した。山中ら ${ }^{20)}$ は 床吹出し空調の場合, 吹出しの風速が高いほど室内空気が混合される 傾向があることを示した．村上ら ${ }^{21)}$ は自由空間と閉鎖空間を想定し た室内に非等温噴流(cold jet)が吹出された際, 流入空気の乱れが室内 気温場の形成に影響を及ぼすことを考察した。

これらのことからも開口部から室内へと流入する空気の乱流混合 程度は室内に形成される上下温度分布や蓄冷程度に大きく影響を及 ぼすと予想される，そのため，外気象条件及び開口部条件ごとに乱流 混合程度を予測できれば, 蓄冷量の推定及び蓄冷に有効な建材の選定 に活用できると考えられる，そこで本研究では，まず開口部条件を固 定した上で, 外気象条件毎に実測により得られた上下温度分布の特徴 を分類する. また分類結果に基づき, 内外気温差・流入風速と蓄冷量 の測定結果を考察し,これらが蓄冷量の推定に有用であることを示す.

\section{2 夜間自然換気時に想定される上下温度分布の特徵と分析方針}

夜間自然換気による蓄冷現象のメカニズムを明らかにするために は, まず換気時の室内気温分布及び気流性状がどのように形成される かについて実態を明確にする必要がある.換気時の室内気温分布や気 流性状に関寸る研究は CFD(Computational Fluid Dynamics)を用い て様々な検討がなされてきた ${ }^{22-24)}$. CFD 計算は室内の詳細な気温 場・気流場の分布も比較的精度良く予測可能であるが, 計算負荷が大 きいことから, 年間計算レベルで蓄泠効果を予測することは困難であ る. 本研究の最終的な目標である環境設計一の応用に向けては, 年間 評価が可能な計算負荷程度が想定される, ブロックモデルによる室内 上下温度分布予測が有用であると考えられる。

既存の室内上下温度分布モデルは暖房時を想定したモデルが多い ため,気流に関しては自然対流を想定したモデルが多い。また自然換 気を想定したブロックモデルとしては, オフィスを対象とした戸河里 ら ${ }^{17)}$ が用いた自由噴流に近い挙動を仮定した噴流モデルがある、本 研究で対象とする現象としては, 居室下部から冷気を取り入れる場合, 一定風速以上であれば, 噴流の軌道によって自由噴流が仮定できるが, 低風速時は噴流の軌道とはならず, 室内空気との混合程度が小さい挙 動を示すと考えられる。また小林ら ${ }^{25)}$ は IJV(Impinging Jet Ventilation)方式が用いられた室内における上下温度分布をより精度 良くかつ簡便に求めるために戸河里らのブロックモデルと CFD 計算 結果から乱流熱拡散係数を同定し, 無次元数を用いて乱流熱拡散係数 の関数式を示すことで, 上下温度分布の簡便な計算方法を示している. しかし, 換気方式の違いやプルーム流の考慮などの点において本研究 で着目している現象とは異なる。

上記の既往研究を踏まえて, 夜間自然換気時の床面への蓄冷効果を 明らかにし，蓄冷量を推定するには，まず Fig.1 に示すように(1)内外 温度差が大きく流入風速が大きい場合, (2)内外温度差が大きく流入風 速が小さい場合, (3)内外温度差が小さく流入風速が大きい場合の特徵 を分析することが有用と考えられる，そこで本研究では，測定期間中 の外気象データに基づき, 上記の 3 点に関してどのような特徴がみら れるかについて次章以降にて分析・考察を行う.

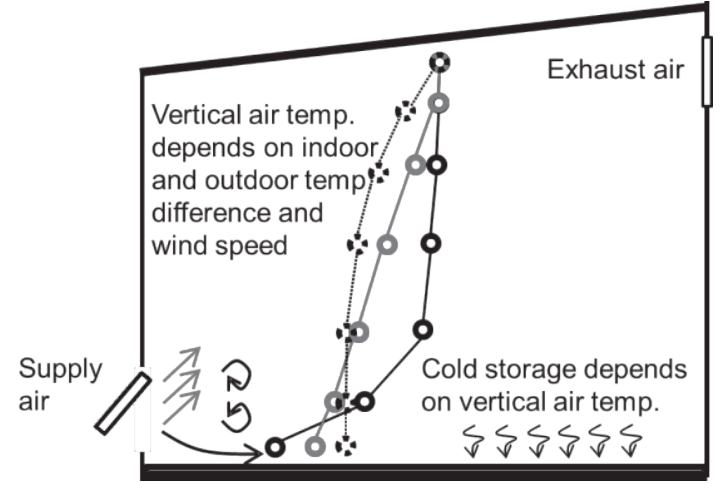

Fig.1 Image of night natural ventilation and cold storage

\section{3. 実測概要}

\section{1 対象建物概要}

対象建物は Table1 に示すように埼玉県熊谷市の木造平屋建の自治 集会所注 1) として建設された建物であり，2014 年 8 月に竣工した. こ のうち実測対象とした空間は，Fig.2(a)の平面図内に示したように Room 1 であり，床面積は $13.3 \mathrm{~m}^{2}$, 天井高は室中央で約 $2700 \mathrm{~mm}$ の 勾配天井の居室である. また Room 1 の床断面は Fig. 3 に示寸通りで あり, フローリング直上の PCM マット $(6 \mathrm{~mm})$ は PCM マット有無に よる違いを測定できるように置敷きとした ${ }^{21}$.

使用した PCM マットは, n-パラフィンを主原料とするマイクロカ プセルを含有した樹脂系マットである. 熱流板法 ${ }^{26)}$ により凝固・融 解時の相変化域を測定した結果を Fig.4 に示す. 過冷却現象のため, 融解時と凝固時では約 $3{ }^{\circ} \mathrm{C}$ 相変化温度域が異なる. $\mathrm{PCM}$ マッ卜敷設 時の内観写真と夜間換気時に開放した開口部仕様を Fig.2(b), (c)に示 す。夜間換気時は地空（開口面積: $0.22 \mathrm{~m}^{2}$, 横过り出し空 : 開き角 度 $30^{\circ} ） 2$ 力所及び引違い空の夕開放した。このうち引違い空前は 地空を想定するため空前面のアルミ製シャッターを F.L +500mm ま で下げた状態（開口面積 : $0.27 \mathrm{~m}^{2}$ ）で測定した.

\section{2 測定概要}

実測は 2014/9/16〜10/20 の期間内に行い注3), 夜間換気の測定は 7 回行った.このうち 4 回（9/16-17，9/19-20，9/22-23，9/25-26）は Room 1 にPCM マットを敷設した状態で行い,残りの 3 回 (9/30-10/1, 10/2-3，10/9-10）は PCM マットを取り除いた状態で測定した. 夜 間換気時間は 20 時〜翌日の 7 時まで（9/16-17 は実測準備のため 22 時〜翌日 6 時まで，9/19-20 と 9/25-26 は 20 時〜 6 時まで）とした. また内部発熱, カーテン等は未設置の状態で測定を行なった。

測定項目及び測定機器設置位置を Table3 と Fig.2(c)に示す. Room 1 には換気によって室内に入る冷気とその分布・混合状況を明 らかにするため鉛直分布 (表面,F.L+0.1m, 0.5m, 1.1m, 1.9m, 2.7m, 天井表面）を 3 か所, 水平分布 (F.L+0.1m) を 7 か所測定した. ま た熱流計を横过り出し空近傍, 室中央, 室奥の 3 か所について PCM マットの上，中，下にそれぞれ設置した。 また「PCM マット無」の 測定時には熱流計を横迄り出し㝒から室の奥まで 5 点設置した. 風速 については, 横汇り出し空と引違い空から屋内外に流れる気流を分析 するため, 各窻付近にそれぞれ超音波風速計を設置した注 4 . また代 表気象については, 同一住宅地内において開発前のため砂利敷となっ ていた周囲の開けた駐車場にて測定した，Room2 は夜間換気を実施 せず PCM 無の条件で，Room1のデータとの比較用として用いた。 


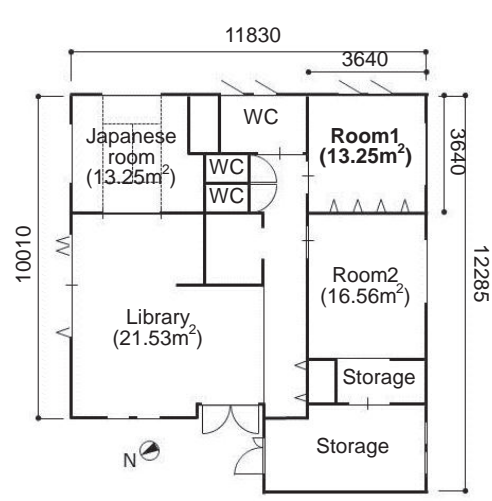

(a) Floor plan

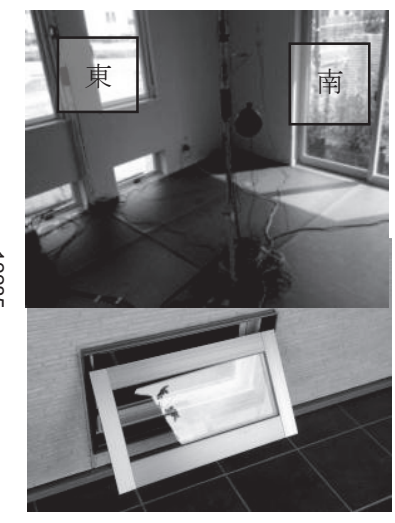

(b) Measurement scene \& awning window shape

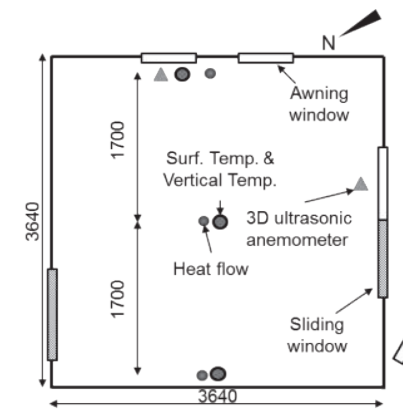

Room1 Floor plan

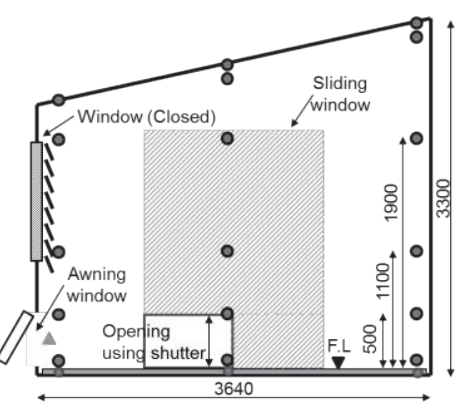

Room1 Cross section (c) Measurement point

Fig.2 Floor plan and measurement point

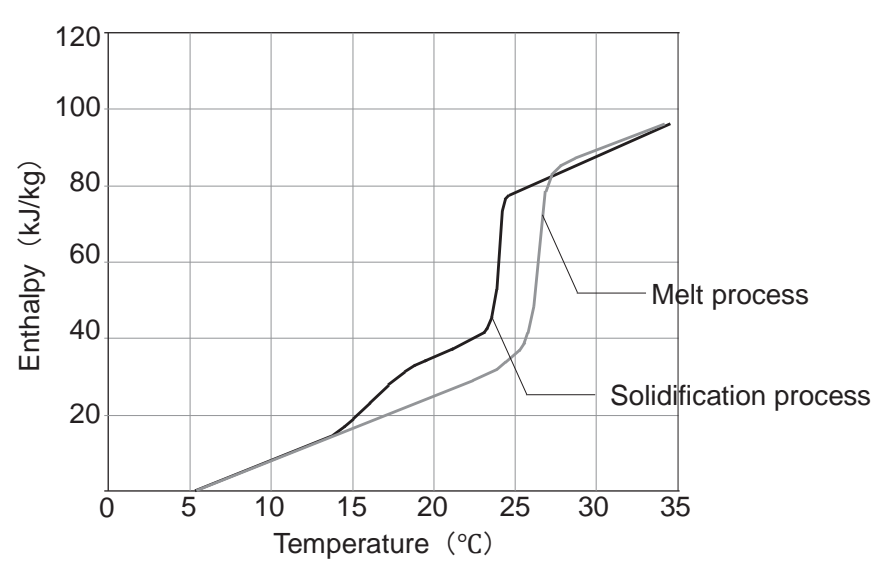

Fig.4 Enthalpy of PCM mat

\section{3 測定日における気象条件の特徵}

前章で指摘したように, 気象条件によって室内気温分布及び気流性 状が異なると予想されるため, 夜間換気が行われた日の気象条件の特

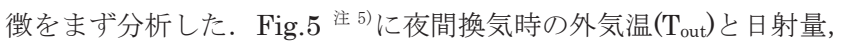

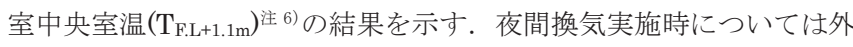
気温が低く風速が比較的高い日 $(9 / 22-23)$, 外気温と風速が高い日 (9/25-26, 10/2-3), 外気温と風速は低い日(10/9-10)等の結果が得られ た。また，夜間換気との比較のため，換気未実施日についても測定を 行い，その中で外気温が高めである日(9/17-18)及び低めである日 (9/27-28)の結果を用いた。これらを Table4にまとめてケース番号を 付した. 次章では, 代表事例としてこれらの日について分析した結果 を示す。
Table1 Specification of target building and area

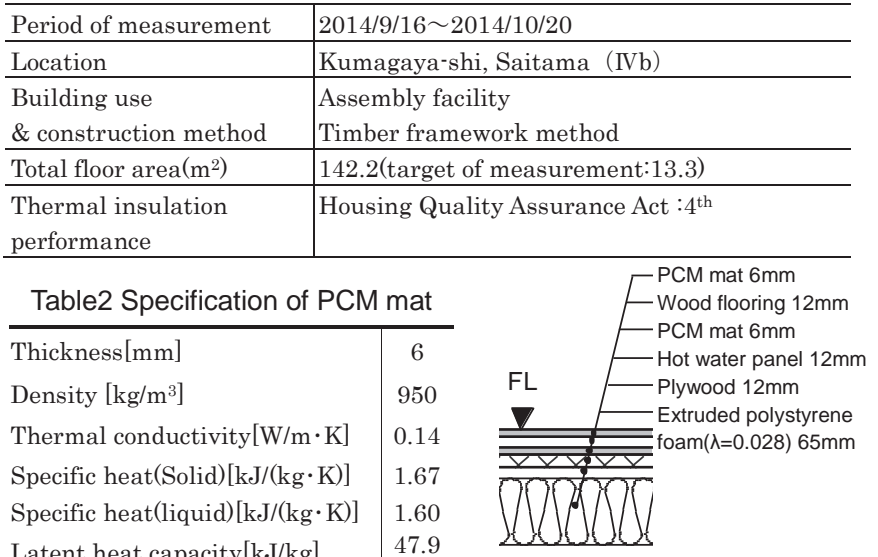

Fig. 3 Cross section of the floor

Table3 Measurement items

\begin{tabular}{l|l}
\hline \multicolumn{1}{c|}{ Items } & \multicolumn{1}{c}{ Instrument } \\
\hline Air temperature & 0.1 -mm $\Phi$ T-type thermocouple \\
\hline Relative humidity & Resistance change type (TDK, CHS-UPS) \\
\hline Globe temperature & $\begin{array}{l}0.1-\mathrm{mm} \Phi \text { T-type thermocouple inside a globe } \\
\text { thermometer }\end{array}$ \\
\hline Surface temperature & 0.3 -mm $\Phi$ T-type thermocouple \\
\hline Heat flow & Heat flow meter (EKO, MF-180),(ETO, M55A) \\
\hline Wind speed in indoor & Air velocity probe (KANOMAX, 0965-09) \\
\hline Wind direction \& speed & $\begin{array}{l}\text { 3D ultrasonic anemometers } \\
\text { (Young-81000): Outdoor measurement } \\
\text { (KAIJO, DA-600): Indoor measurement }\end{array}$ \\
\hline & $\begin{array}{l}\text { Air temp. :0.1-mm } \Phi \text { T-type thermocouple } \\
\text { Humidity:Resistance change type } \\
\text { (TDK, CHS-UPS) }\end{array}$ \\
Weather data & $\begin{array}{l}\text { Wind:Wind vane anemometer (EKO, MA-110) } \\
\text { Solar radiation:Thermopile pyranometer }\end{array}$ \\
\hline
\end{tabular}

Table4 Measurement information

\begin{tabular}{|c|c|c|c|}
\hline Case No. & Date & PCM & Time of N.V \\
\hline Case 1 & $9 / 17-18$ & \multirow{5}{*}{ With PCM } & Not Implement \\
\hline Case 2 & $9 / 19-20$ & & 20p.m. - 6a.m. \\
\hline Case 3 & $9 / 22-23$ & & 20p.m. - 7a.m. \\
\hline Case 4 & $9 / 25-26$ & & 20p.m. - 6a.m. \\
\hline Case 5 & $9 / 27-28$ & & Not Implement \\
\hline Case 6 & $10 / 2-3$ & \multirow{2}{*}{ Without PCM } & 20p.m. - 7a.m. \\
\hline Case 7 & $10 / 9-10$ & & 20p.m. - 7a.m. \\
\hline Case 8 & $9 / 22-23$ & Without PCM (Room2) & Not Implement \\
\hline
\end{tabular}

\section{4. 室内上下温度分布の分析}

本章では夜間自然換気時の上下温度分布の特徴を流入風速及び内 外気温差に着目し，分析した結果を示す。

\section{1 室内上下温度分布の特徵}

Fig.6 に室内に形成される上下温度分布の日付別 - 測定点別の結果 を示す，夜間換気未実施日の(e) Case 5, (f) Case 8 では, 上下間の 気温差も $0.5^{\circ} \mathrm{C}$ 以内に収まっており, 室内気温場が安定していること が分かる. 一方夜間換気実施日である(a) Case 3, (c) Case 6, (d) Case 7 では, 開口部開放前後の 19 時と 20 時の上下温度分布を比較すると, 床表面近傍温度が最大約 $4{ }^{\circ} \mathrm{C}$ 低下しており, 夜間換気により室内の上 下温度分布が変化している.

Case 7 は夜間を通して流入風速が非常に低い $(0.1 \mathrm{~m} / \mathrm{s}$ 以下）ため 


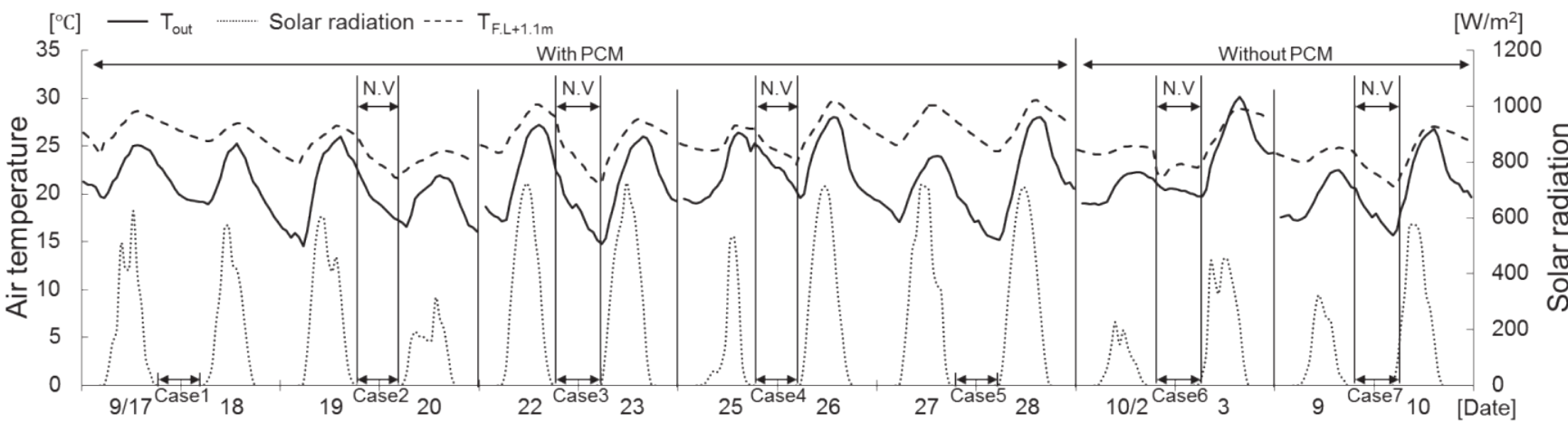

(a) Solar radiation, outdoor and indoor $(F . L+1.1 \mathrm{~m})$ temperature

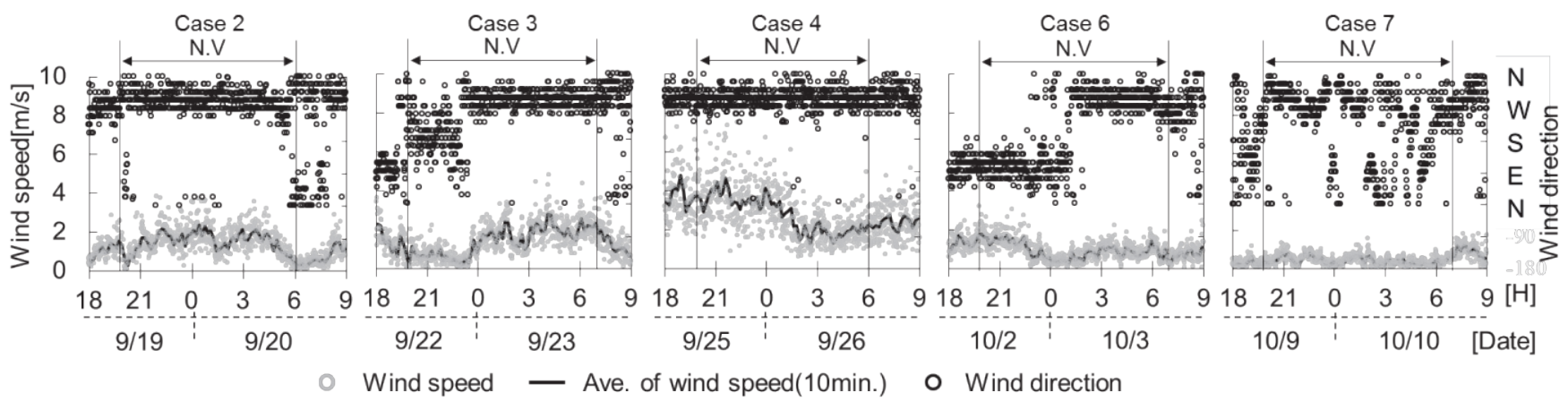

(b) Wind speed and direction of night ventilation(N.V) period

Fig. 5 Weather data of measurement period

外部空気が床近傍に堆積し, 上部空気との混合程度が小さく床近傍気 温が上部気温より $2.5 \sim 3.0^{\circ} \mathrm{C}$ 程度低い状態で推移している. Case 3 の $22 \sim 23$ 時も同様であり, 床近傍(F.L + 0.1m)の気温低下幅が他時刻 よりも $1^{\circ} \mathrm{C}$ 程度大きい。これは流入風速が低い $(0.1 \mathrm{~m} / \mathrm{s}$ 程度 $)$ ため温 度差換気が卓越し, 温度成層が形成されて室内で上下間の乱流混合が 起こり難いことが要因として考えられる. 即ち外部風速が低い場合, 流入空気は室内空気との混合程度が小さく,下層部に冷気が堆積した 状態となる

Case 3 の他の時間帯には一定程度の流入風速（平均 $0.2 \mathrm{~m} / \mathrm{s}$ 前後） があり，鉛直方向の温度勾配が約 $1.5^{\circ} \mathrm{C} / \mathrm{m}$ 程度で形成されている.こ れは開口部上端を越える高さまで流入空気が吹き上げられ, 流入空気 が室内空気と混合されるためであると考えられる.

また Case 4 では 20〜 1 時までと 2 時以降の室内気温分布がやや異 なる. $20 \sim 0$ 時までは流入風速が $0.2 \mathrm{~m} / \mathrm{s}$ 以上であり，その影響で上 記と同様に室内上部にも気温の鉛直勾配ができている. 但し内外気温 差が小さいため床近傍から天井近傍の気温差が $1^{\circ} \mathrm{C}$ 程度と小さい. た 1 時以降は流入風速が低下したため, 室内上部への流入空気の混合 が進まず床近傍に冷気が堆積したため, 床近傍と天井近傍気温の差が $2.5^{\circ} \mathrm{C}$ 程度に広がっている. Case 6 でも $20 \sim 0$ 時までの上下温度分布 と $1 \sim 6$ 時までの分布の特徵が異なっている. 外部風速が 0 時ごろか ら弱まった影響で上下温度分布特性が変化したものと考えられる. 但 し内外気温差が大きくないため, 室内気温低下への影響は小さい.

以上のことから, 地空を持つ二面開口単室空間の室内上下温度分布 は，流入平均風速が $0.1 \mathrm{~m} / \mathrm{s}$ 程度の変化で異なる気流性状を示し，流 入する冷気の混合程度にも影響を及ぼしていた，そのため，内外気温 差が同程度であっても, 流入風速の違いで床表面近傍の気温低下幅が 異なっていた。

\section{2 上下温度分布形成に影響する要因}

前節の結果を踏まえて, 本節では夜間自然換気の際に室内上下温度 分布に影響を及ぼす主要なパラメータである内外気温差及び流入風 速と鉛直方向の温度勾配の関係について考察する. そのため, 浮力と 慣性力の比を代表するアルキメデス数( $\mathrm{Ar}$ 数)を用いて分析を行う.

$$
A r=\frac{g \beta \sqrt{A}\left(T_{F . L+1.1 m}-T_{i n}\right)}{v_{i n}^{2}}
$$

$A r$ : アルキメデス数 $(-) g:$ 重力加速度 $\left(\mathrm{m} / \mathrm{s}^{2}\right) \quad \beta$ : 空気の体積膨張率 $(1 / \mathrm{K})$ $A$ : 開口面積 $\left(\mathrm{m}^{2}\right) \quad T_{F . L+1.1 m}$ : 室中央の $\mathrm{F} . \mathrm{L}+1.1 \mathrm{~m}$ での気温 $\left({ }^{\circ} \mathrm{C}\right) T_{\text {in }}$ : 流入空気 温度 $\left({ }^{\circ} \mathrm{C}\right) v_{\text {in }}:$ 流入風速 $($ 地空 $)(\mathrm{m} / \mathrm{s})$

Fig.7 に隣接する上下間の温度差 $\left(\Delta \mathrm{T}_{\mathrm{b}}\right)$ と, 室における $\mathrm{Ar}$ 数との関 係を 15 分間刻別にプロットした結果を示す. 開口高さである F.L $+0.5 \mathrm{~m}$ までは $\mathrm{Ar}$ 数と $\Delta \mathrm{T}_{\mathrm{b}}$ が比例関係であることが分かり, 上部 に行くほどその関係性が弱まっている傾向を示している. 即ち, 室下 部においては $\mathrm{V}_{\text {in }}$ が高くなると $\Delta \mathrm{T}_{\mathrm{b}}$ が小さくなり， $\Delta \mathrm{T}$ が大きくなる と $\Delta \mathrm{T}_{\mathrm{b}}$ も大きくなると考えられる. しかしながら, 室上部にいくほど, 相関がなくなるのは流入する空気の到達高さや上部に達するまでの 室内空気との混合など他の要因が含まれていると考えられる.

Fig.8に $\mathrm{V}_{\text {in }}$ が $0.1 \mathrm{~m} / \mathrm{s}$ 未満である場合の $\mathrm{V}_{\text {in }}$ と $\Delta \mathrm{T}_{\mathrm{b}}$ との関係を示す. 室の最下部では $V_{\text {in }}$ に対して $\Delta \mathrm{T}_{\mathrm{b}}$ の変化に相関がみられていない. ま た最下部において $\Delta \mathrm{T}_{\mathrm{b}}$ が $1^{\circ} \mathrm{C}$ 前後と $2^{\circ} \mathrm{C} \sim 2.5^{\circ} \mathrm{C}$ 間でプロットされる のは各実測日における $\Delta \mathrm{T}$ の差に起因するものである.また F.L $+0.5 \mathrm{~m}$ より上部では実測日に関わらず $\mathrm{V}_{\text {in }}$ が高くなると $\Delta \mathrm{T}_{\mathrm{b}}$ も大きくなる傾 向を示している.

以上を踏まえ, 今回の測定結果より得られた各気象条件における室 内上下温度分布の特徵を分類した結果を Fig.9 に示寸. (a) 流入風速 

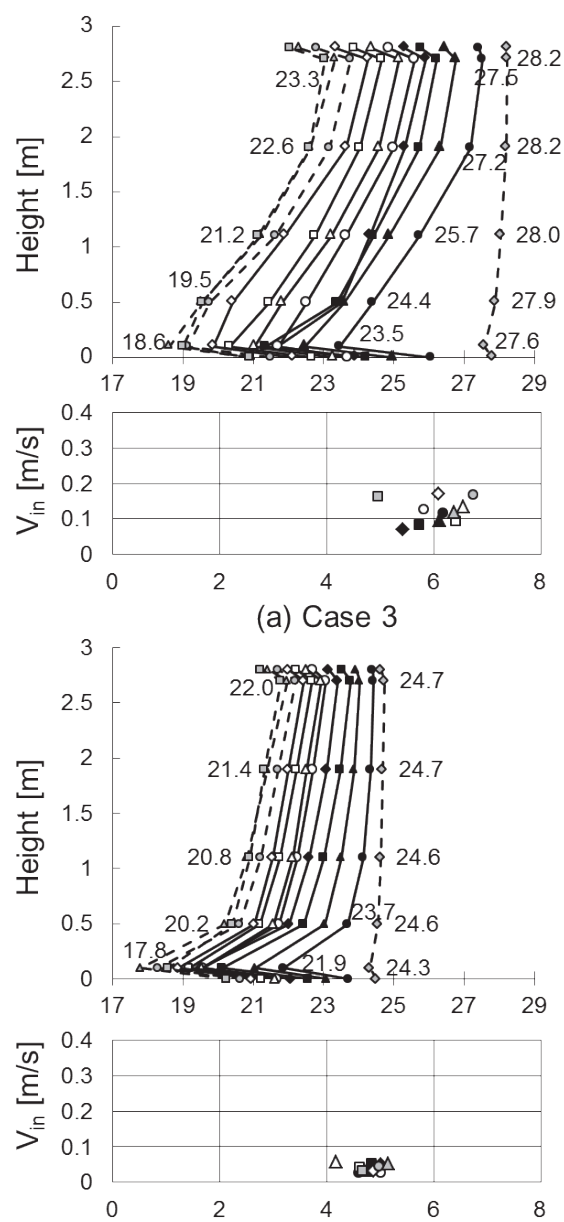

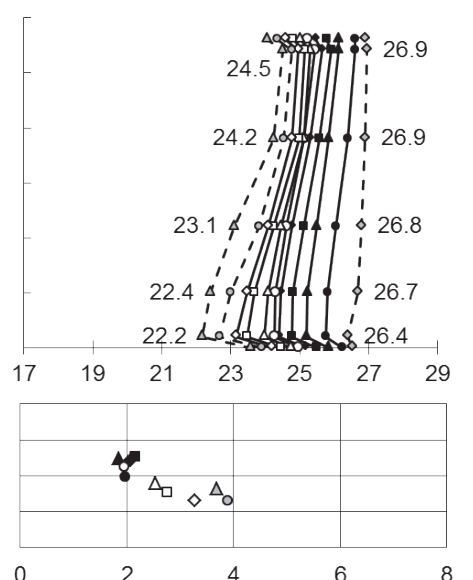

(b) Case 4

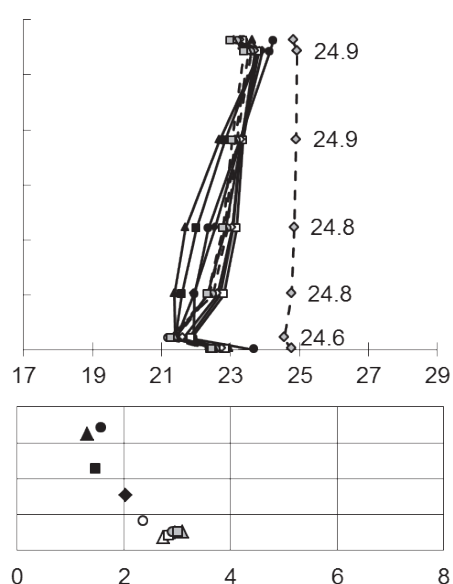

(c) Case $6 \quad \Delta \mathrm{T}\left[{ }^{\circ} \mathrm{C}\right]$

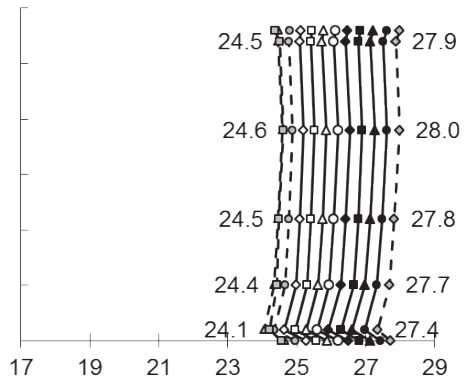

(e) Case 5

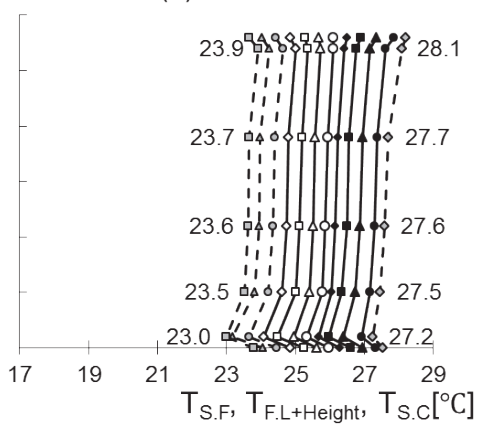

(f) Case 8

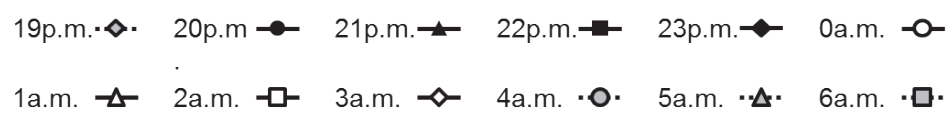

(d) Case $7 \quad \Delta \mathrm{T}\left[{ }^{\circ} \mathrm{C}\right]$

Fig. 6 Vertical air temperature distribution in the room 1 and room 2

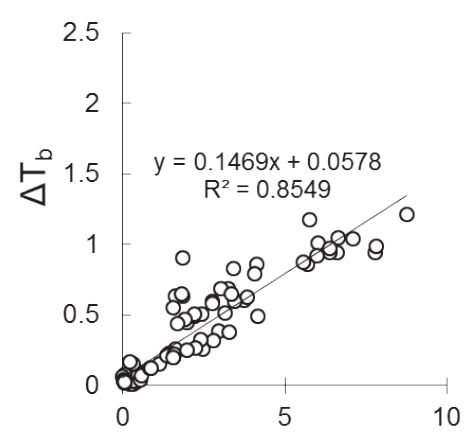

(a) $T_{F . L+0.5 m}-T_{F . L+0.1 m}$

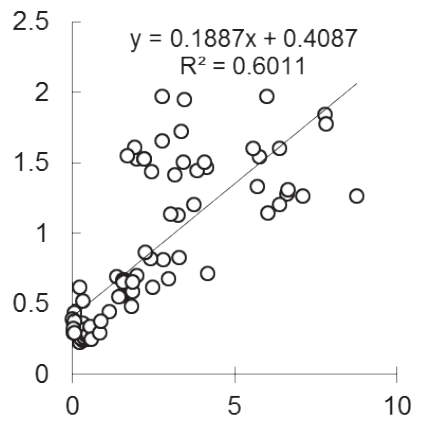

(b) $T_{F . L+1.1 m}-T_{F . L+0.5 m}$

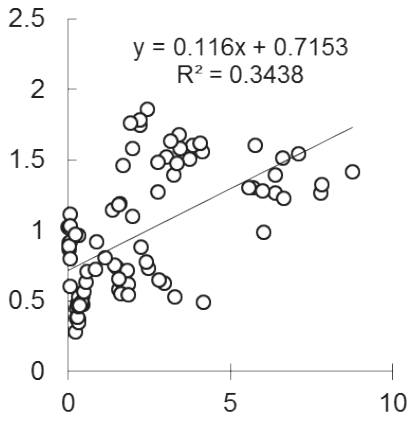

(c) $T_{F . L+1.9 m}-T_{F . L+1.1 m}$

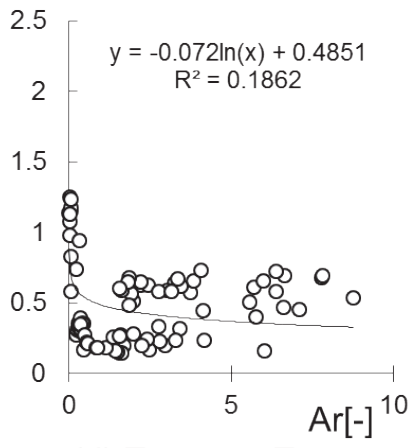

(d) $T_{F . L+2.7 m}-T_{F . L+1.9 m}$

Fig.7 Correlation between Archimedes number of the room and air temperature difference of each block $\left(V_{\text {in }} \geq 0.1 \mathrm{~m} / \mathrm{s}\right)$

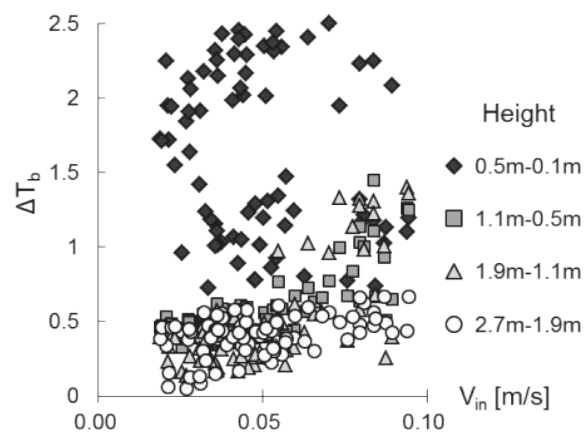

Fig. 8 Correlation between $V_{\text {in }}$ and $\Delta T_{b}$ $\left(V_{\text {in }}<0.1 \mathrm{~m} / \mathrm{s}\right)$

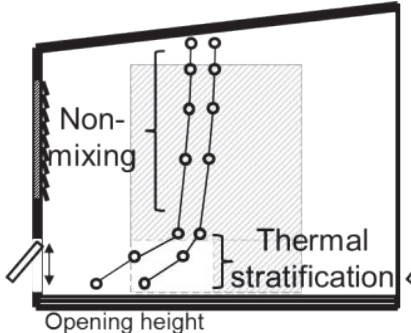

(a) $V_{\text {in }}$ : under $0.1 \mathrm{~m} / \mathrm{s}$

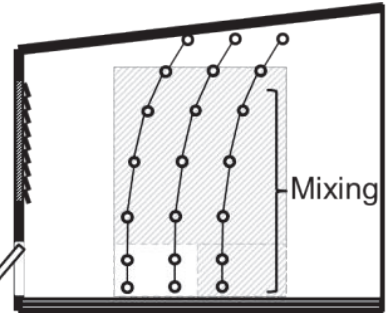

(c) $V_{\text {in }}$ : over $0.3 \mathrm{~m} / \mathrm{s}$

Fig. 9 Classification of shape of vertical air temperature distribution by wind speed 
$0.1 \mathrm{~m} / \mathrm{s}$ 未満では, 開口部高さ程度まで内外気温差に応じた温度勾配 が生じるが, 開口部高さを超える空間においては気温差がほぼ見られ なかった（b) 一方室内流入風速が $0.2 \mathrm{~m} / \mathrm{s}$ 前後の時, $\mathrm{Ar}$ 数に応じた 温度勾配がみられた. 温度勾配の大きさは $\mathrm{Ar}$ 数により決定される傾 向を示しており，(c) 流入風速が $0.3 \mathrm{~m} / \mathrm{s}$ を超えるとそれに応じて室 下部の空気は完全混合され気温差がほぼ無くなる傾向が見られた.

次章では，本章を踏まえ蓄冷量に影響を与えるパラメータとして， 床表面近傍温度と床表面温度との差 $\left(\Delta \mathrm{T}_{\mathrm{a}}\right)$ について考察する.

\section{5. 夜間自然換気による潜熱蓄熱材への蓄冷量評価}

前章迄の知見を踏まえ, 本章では各気象条件における気温分布及び 気流性状が PCM の蓄冷量に与える影響について PCM 温度測定結果 により分析する.

\section{1 外部気象条件別の蓄冷量注 7 ) の評価}

Fig.10 に下式(2)〜 (4)により算出した各実測期間における日積算蓄 冷量 $(\mathrm{CS})$ 及び夜間換気時 $($ Case 2-4)における外気温と風速の最大・最 小・平均值を示す.また比較のため夜間換気未実施日(Case1, Case5) についても示す.夜間換気未実施日には相変化温度域まで表面温度が 低下しなかった。一方，夜間換気実施日における積算蓄冷量（顕熱・ 潜熱）は外気温が実測期間中最低の日である Case3 で最大となり， 潜熱分が約 7 割であった。 また Case 4 では風速は一定程度あるが外 気温が比較的高い $\left(19.4 \sim 24.1^{\circ} \mathrm{C}\right)$ ため, Case 3 に比べ顕熱は約 $40 \%$, 潜熱は約 $70 \%$ の蓄冷量であった. Case2 も Case 3 より外気温が平均 で $1.3^{\circ} \mathrm{C}$ 高いため，顕熱が約 $70 \%$ ，潜熱は PCM マットの温度が相変 化温度以下となるため同量となり, 夜間換気時の外気温によって蓄冷 量に約 1.5 倍程度の差がみられた。

$$
\begin{aligned}
& C S=Q_{s}+Q_{l} \\
& Q_{s}=C_{s, p} \rho l A_{f}\left\{\left(T_{s 1}-T_{e 1}\right)+\left(T_{s 2}-T_{e 2}\right)\right\} \\
& Q_{l}=C_{l, p} \rho l A_{f}\left(\Delta T_{1}+\Delta T_{2}\right) \quad\left(23.5 \leq \mathrm{T}_{1,2} \leq 24.5^{\circ} \mathrm{C} \text { の時 }\right)
\end{aligned}
$$

$C S$ :日積算蓄冷量[kJ/day] $Q_{S}$ :䫓熱蓄冷量[kJ/day $Q_{l}$ 潜熱蓄冷量[kJ/day $C_{s, p}$ : 比熱 $[\mathrm{kJ} / \mathrm{kgK}] \rho$ :密度 $\left[\mathrm{kg} / \mathrm{m}^{3}\right] l$ :厚さ $[\mathrm{m}] A_{f}$ :床面積 $\left[\mathrm{m}^{2}\right] T_{s}$ :換気開始時温度 $T_{e}$ : 換気終了時温度 $T: \mathrm{PCM}$ マット温度 $\left.{ }^{\circ} \mathrm{C}\right] C_{l, p}$ : 相変化温度時における見かけの比 熱(潜熱分) $[\mathrm{kJ} / \mathrm{kgK}] \Delta T$ : 相変化温度域における PCM 温度低下量 添え字(1:上 部 PCM, 2: 下部 PCM)

Fig.11 に，夜間換気実施日における 15 分ごとの積算蓄冷量 $\left(\mathrm{CS}_{15}\right)$ と床近傍気温と床表面温度との差 $\left(\Delta \mathrm{T}_{\mathrm{a}}\right)$, 流入風速 $\left(\mathrm{V}_{\mathrm{in}}\right)$, 対流熱伝達 率の無次元数である $\mathrm{Nu}$ 数及び $\Delta \mathrm{T}_{\mathrm{a}}-\Delta \mathrm{T}, \Delta \mathrm{T}_{\mathrm{a}}-\mathrm{V}_{\text {in }}$ との関係を示す. こ の結果から蓄冷量は内外気温差 $(\Delta \mathrm{T})$ が大きい Case 2,3 では, 流入風 速 $\left(\mathrm{V}_{\text {in }}\right)$ に反比例する傾向がある.また $\Delta \mathrm{T}$ が小さい Case 4 では風速が 高くなっても得られる蓄冷量は限定的である. また, $\mathrm{CS}_{15}-\mathrm{Nu}$ 数のグ ラフをみると $\mathrm{Nu}$ 数は各ケースとも 50〜100 の範囲内で大きく異な らず，蓄冷量と最も相関が高かったのは内外気温差であった注 ${ }^{8)}$. 従 って, $\Delta \mathrm{T}$ が大きく $\mathrm{V}_{\text {in }}$ が低い時, 床面への蓄冷が促進され， $\Delta \mathrm{T}$ が小 さい時は，流入風速にかかわらず蓄泠効果は小さい傾向がみられた．

\section{2 気流・気温性状が蓄冷量に与える影響}

Fig.12に, 以上の結果から得られた外部気象条件ごとの室内上下 温度分布, 開口部・床面近傍の気流性状が PCM マットへの蓄冷に寄 与寸る傾向を示寸．蓄冷量は外部気温に依存する度合いが高く,内外 気温差が大きいほど大きくなる傾向がある.また内外気温差が大きく ても流入風速が高い時 $(\mathrm{Vin} \geq 0.2 \mathrm{~m} / \mathrm{s})$ は, 流入風速が低い時
$(\mathrm{Vin}<0.1 \mathrm{~m} / \mathrm{s})$ に比べ蓄冷量がやや減少する傾向がある. 流入風速が高 い場合は室内上部空気との乱流混合によって床近傍気温が高くなり, 流入風速が低い時は外部から入る冷気が床に沿って堆積し, 床近傍気 温が低下するためと考えられる. また内外気温差が小さい場合は風速 に関係なく蓄冷量は限定的である。

\section{6. まとめ}

本研究では, 地空を用いて夜間自然換気を実施した際に形成され る, 室内上下温度分布を内外気温差及び流入風速に基づいて分類した. その結果を踏まえて, 床面に敷設した PCM マットへの蓄冷現象を分 析し, PCM マットの蓄冷が促進される条件を明らかにした，以下に 本研究で得られた知見を示す.

（i）室内に生じる上下温度分布は内外気温差及び流入風速に影響 された. 流入風速が $0.1 \mathrm{~m} / \mathrm{s}$ 以下である場合, 冷気が床近傍に堆 積するため, 地空相当高さまで内外気温差に応じた温度勾配がみ られた. $0.2 \mathrm{~m} / \mathrm{s}$ 前後の時は床近傍から開口部高さを超える室の上 部まで温度勾配がみられた。温度勾配の生成高さは $\mathrm{Ar}$ 数により 決定された．また， $0.3 \mathrm{~m} / \mathrm{s}$ 以上である場合，少なくとも地空相当 の高さ迄は内外空気の乱流混合により気温差が小さくなる傾向 を示した。

（ii） PCM マットへの蓄冷量は夜間換気時, 顕熱蓄冷が 3 割, 潜熱 蓄冷が 7 割程度となり, 外気温によって積算蓄冷量 (顕熱・潜熱) に約 1.5 倍程度の差がみられた。

（iii） PCM マットへの蓄冷量は内外気温差が大きく流入風速が低い 時, 床面一の蓄冷が促進され, 内外気温差が小さい時は, 流入風 速にかかわらず蓄冷効果は小さい結果となった。

本研究では, 実建物を対象として流入風に対する上下温度分布の形 成要因に着目して分析を行った. 実測結果からのみ乱流拡散係数や熱 移動係数を同定することは困難であることから, 今後は CFD 解析に 基づいた乱流拡散係数を同定した上で, ブロックモデルに基づく上下 温度分布予測をする. そして, 夜間自然換気時の室内上下温度分布と PCM の熱物性を組み込んだ室内熱負荷計算モデルの開発及び PCM の蓄冷量・熱負荷削減効果の予測・評価を行う予定である. また PCM のパッシブクーリング住宅への導入に向けて夜間自然換気の翌日の 朝方から日中にかけての持続効果及びその効果を最大化するための ライフスタイルを考慮したクーリング手法の組み合わせを検討する.

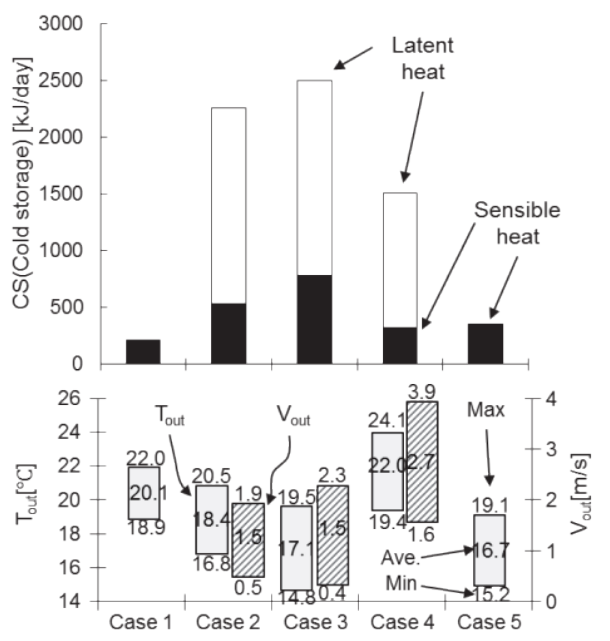

Fig.10 Cold storage of PCM on each measurement day 
記号

$\Delta \mathrm{T}:$ 内外気温差 $\left[{ }^{\circ} \mathrm{C}\right]$

$\mathrm{T}_{\text {out }}$ : 外部気温 $\left[{ }^{\circ} \mathrm{C}\right]$

$\mathrm{T}_{\text {in }}$ : 流入空気温度 $\left[{ }^{\circ} \mathrm{C}\right]$

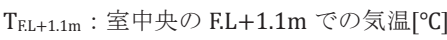

$\mathrm{T}_{\mathrm{S} . \mathrm{F}}$ : 床表面温度 $\left[{ }^{\circ} \mathrm{C}\right]$

$\mathrm{T}_{\mathrm{S} . \mathrm{C}}$ : 天井表面温度 $\left[{ }^{\circ} \mathrm{C}\right]$

$\Delta \mathrm{T}_{\mathrm{a}}: \mathrm{T}_{\mathrm{F} . \mathrm{L}+0.1 \mathrm{~m}}$ と $\mathrm{T}_{\mathrm{S} . \mathrm{F}}$ との気温差 $\left[{ }^{\circ} \mathrm{C}\right]$

$\Delta \mathrm{T}_{\mathrm{b}}$ : ブロック間の気温差（例 : $\mathrm{T}_{\mathrm{F} . \mathrm{L}+0.5 \mathrm{~m}}-\mathrm{T}_{\mathrm{F} . \mathrm{L}+0.1 \mathrm{~m}}$ ) $\left[{ }^{\circ} \mathrm{C}\right]$

$\mathrm{V}_{\text {out }}$ : 外部風速 $[\mathrm{m} / \mathrm{s}]$

$\mathrm{V}_{\text {in }}$ : 流入風速 $($ 地空 $)[\mathrm{m} / \mathrm{s}]$

$A$ : 開口面積 $\left[\mathrm{m}^{2}\right]$

注

注 1）今回実測対象の集会所は，引渡し前の建物ということもあり，機械換気 は使用していない。

注 2）フローリング直下の PCM マットは熱抵抗が大きいことから, 夏季のパッ シブな利用は難しいと考えられるため,ここでは主に置敷きの PCM マッ トに着目する。

注 3）恒温槽を用いて夜間換気を模擬した予備実験の結果より,室温を $22^{\circ} \mathrm{C}$ 程 度まで降下させることが今回の PCM マットを凝固させるには有効との結 果が得られていたことから, 最低外気温が $22^{\circ} \mathrm{C}$ 以下となる頻度が高くなる 9 月中旬より実測を行った。 今回の PCM の相変化温度域は，初夏や残暑 の利用を想定したものであるが，実運用上の最適な相変化温度域について は、検討中である。

注 4）超音波風速計のデータ（流入風速に関するデータ）については主に流入 側となっていた横之り出し空側のデータを分析に使用した.

注 5）室内への流入風速を基準として議論しているため外部気象条件の上空風 向に関しては記述していないが，一部の時間帯 (9/22-23の 20 時〜23 時 : 南南西〜南南東， $10 / 2-3$ の 20 時〜 1 時: 東風）を除き殁どの夜間自然換 気の時間带は北西風 (今回対象部屋の開口部を基準としては風下側となる) が主風向となった。但し，隣接建物や公園等の影響で建物周りの風向が変 化していたものと考えられるため，本文中流入風速 $\left(V_{\text {in }}\right)$ の值は室内地空近 傍にて 3 次元超音波風速計で測定した “室内一流入する風速”とする.

注 6）室内を代表する気温は室中央部の F.L+1.1m の気温を用いる。内外気温 差は“外気温と室中央の気温差”とする $\left(\Delta \mathrm{T}=\mathrm{T}_{\mathrm{F} . \mathrm{L}+1.1 \mathrm{~m}}-\mathrm{T}_{\mathrm{out}}\right)$.
注 7）本実測は主に夜間自然換気による蓄冷に着目しているが，放熱時間带の データも取得しており必ずしも蓄冷と放熱は前日の履歴の影響等も受け てバランスしていない。これは前日夜間蓄冷効果により日中室温上昇が抑 えられ，潜熱蓄熱分が必ずしも全て放熱時に使いきれていない場合あるた めである

注 8)この結果は今回の実測条件に基づいたものであり,内外気温差が大きく, 流入風速が高いなど議論できていないケースがあるため, 他の条件を考慮 した場合, $\mathrm{Nu}$ 数と蓄冷量との相関がある可能性がある.

\section{参考文献}

1) Kiyota, N. and Sekine, T. : Experimental study on pressure loss at the openning of wall surface (PART II), Journal of Architecture, Planning and Environmental Engineering (Transactions of AIJ), No. 398, pp. 47-57, 1989. 4 (in Japanese) 清田誠良, 関根毅 : 模型壁面の開口部圧力損失に関する実験的研究(続報), 日本建築学会計画系論文報告集，第 398 号, pp. 47-57, 1989. 4

2) Akabayashi, S. Murakami, S. Mizutani, K. and Takakura, S. : Wind tunnel test on surface wind pressure and prediction of air change rate of detached house : Experimental study on natural ventilation of detached House Part 1, Journal of Architecture, Planning and Environmental Engineering (Transactions of AIJ), No. 456, pp. 9-16, 1994. 2(in Japanese) 赤林伸一，村上周三，水谷国男，高倉秀一：周辺に建物群のある独立住宅の 風圧分布に関する風洞実験および換気量予測 : 住宅の換気・通風に関する実 験的研究 その 1 , 日本建築学会計画系論文集, 第 456 号, pp. 9-16, 1994.2

3) Sawachi, T. Seto, H. Kiyota, N. Narita, K. and Ishikawa, Y. : Characteristics of the wind tunnel with a full-scale building model specially designed for cross ventilation research, Journal of Environmental Engineering (Transactions of AIJ), No. 598, pp. 37-44, 2005. 12 (in Japanese)

澤地孝男，瀬戸裕直，清田誠良，成田健一，石川優美：実大建物模型を用い た通風研究専用風洞実験施設の特性, 日本建築学会環境系論文集, 第 598 号, pp. 37-44, 2005. 12

4) Ohba, M. Kurabuchi, T. Goto, T. Endo, T. and Akamine, Y. : Investigation on applicability of local dynamic similarity model for inflow openings Prediction accuracy of flow rate of cross-ventilated buildings (Part 2), Journal of Environmental Engineering (Transactions of AIJ), No. 617, pp. 25-30, 2007. 7 (in Japanese)
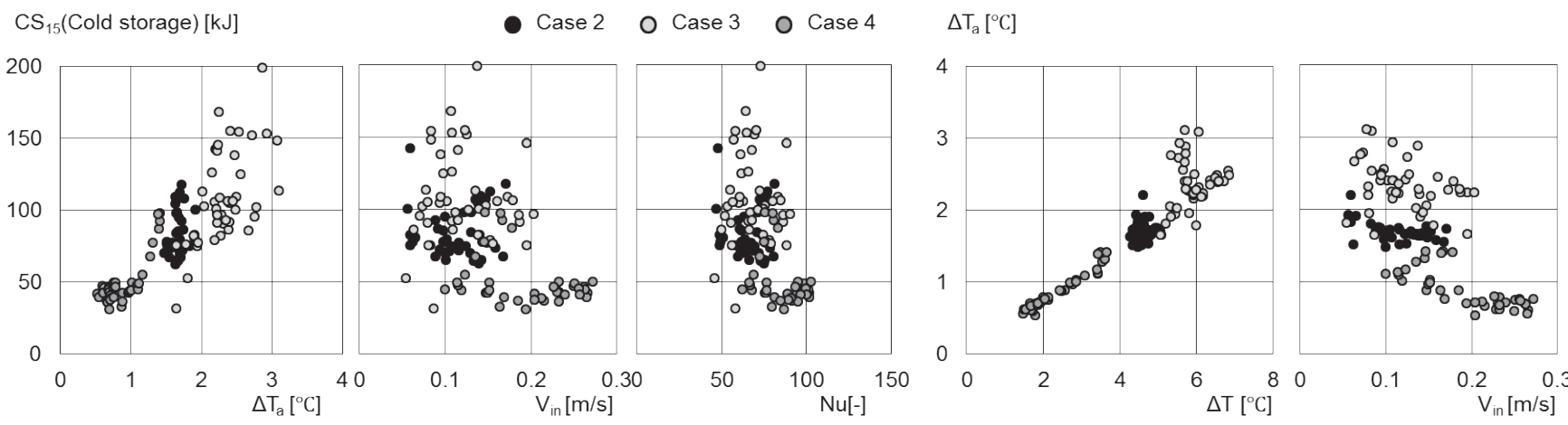

Fig.11 Correlation $\mathrm{CS}_{15}-\Delta \mathrm{T}_{\mathrm{a}}, \mathrm{CS}_{15}-\mathrm{V}_{\text {int }}, \mathrm{CS}_{15}-\mathrm{Nu}, \Delta \mathrm{T}_{\mathrm{a}}-\Delta \mathrm{T}, \Delta \mathrm{T}_{\mathrm{a}}-\mathrm{V}_{\text {in }}$
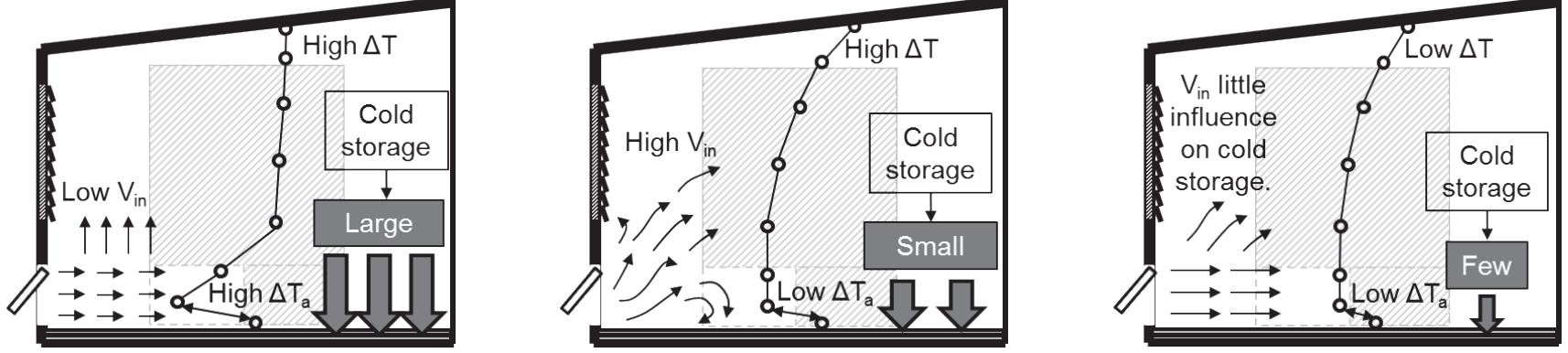

Fig.12 Parameters influence in cold storage and indoor thermal characteristics 
大場正昭，倉㴊隆，後藤伴延，遠藤智行，赤嶺嘉彦，野中俊宏 : 流入開口部 における局所相似モデルの適用性に関する検討 : 通風時の換気量予測法に関 する研究(第 2 報)，日本建築学会環境系論文集，第 617 号, pp. 25-30, 2007. 7

5) F, Flourentzou. J, Van der Maas. C,-A, Roulet. : Natural ventilation for passive cooling : measurement of discharge coefficients, Energy and Buildings, Vol. 27, pp. 283-292, 1998

6) H, Montazeri. B, Blocken. : CFD simulation of wind-induced pressure coefficients on buildings with and without balconies : Validation and sensitivity analysis, Building and Environment, Vol. 60, pp. 137-149, 2013

7) R, T, Muehleisen. S, Patrizi. : A new parametric equation for the wind pressure coefficient for low-rise buildings, Energy and Buildings, Vol. 57, pp. 245-249, 2013

8) Seri, K. Tanaka, T. et al. : Experimental Study on Basic Performance of Air-conditioning System with Floor Thermal Storage : Part5 and 6, Summaries of Technical Papers of Annual Meeting, Architectural Institute of Japan, Environmental Engineering-II, pp. 137-140, 1999 (in Japanese)

世利公一，田中崇浩他：躯体蓄熱空調システムの基本性能に関する実験的研 究 その 5, 6, 日本建築学会大会学術講演梗概集, D- II, pp. 137-140, 1999

9) Misaka, I. Higuchi, M. Takahashi, N. Sako, H. Takai, H. and Hanzawa, H. : Evaluation of Energy Conservation Effect by Predicting Simulation and Measurements for Office Building with Natural Ventilation and Night Purge System, Journal of SHASE, No. 82, pp. 39-48, 2001. 7 (in Japanese)

三坂育正, 樋口祥明, 高橋紀行, 迫博司, 高井啓明, 半澤久 : 自然換気・ナ イトパージシステムを導入した事務所ビルにおける省エネルギー効果の予 測と実測評価, 空気調和・衛生工学会論文集, 第 82 号, pp. 39-48, 2001.7 10) B, Givoni. : Comfort, climate analysis and building design guidelines, Energy and Buildings, Vol. 18, pp. 11-23, 1992

11) B, Givoni. : Effectiveness of mass and night ventilation in lowering the indoor daytime temperatures. Part 1: 1993 experimental periods, Energy and Buildings, Vol. 28, pp. 25-32, 1998

12) V, Geris. M, Santamouris. A, Tsangrasoulis. G, Guarracino. Experimental evaluation of night ventilation phenomena. Energy and Buildings, Vol. 29, pp. 141-154, 1999

13) M, Santamouris. D, Kolokotsa. : Passive cooling dissipation techniques for buildings and other structures: The state of the art. Energy and Buildings, Vol. 57, pp. 74-94, 2013

14) Kim, S. Kindaichi, S. Akamine, Y. Mae, M. and Sakamoto, Y. : Study on energy saving floor heating system using air to water heat pump : Part 1 Evaluation of thermal characteristics of floor heating panels, Journal of Environmental Engineering (Transactions of AIJ) Vol. 74, No. 637, pp. 379-387, 2009. 3 (in Japanese)

金秀耿, 金田一清香, 赤嶺嘉彦, 前真之, 坂本雄三 : 温水ヒートポンプを用 いた省エネルギー型床暖房システムに関する研究 : 第 1 報 床暖房パネルの 放熱特性の評価, 日本建築学会環境系論文集, 第 74 巻, 第 637 号, pp. 379-387, 2009. 3

15) Sato, Y. Ozaki, A. Nakamura, T. Hayashi, Y. and Ishiguro, S. : Research on the reduction effect of the space heating load by latent heat storage interior building materinal : Examination by a model box experiment, a test house experiment, and a numerical simulation, Journal of Environmental Engineering (Transactions of AIJ) Vol. 77, No. 678, pp. 651-659, 2012. 8 (in Japanese)

佐藤友紀，尾崎明仁，中村哲己，林禎彦，石黒成紀 : 潜熱蓄熱内装建材によ る暖房負荷の削減効果に関する研究:模型箱実験・試験家屋実験および数值シ ミュレーションによる検討, 日本建築学会環境系論文集, 第 77 巻, 第 678 号, pp. 651-659, 2012.8

16) Ito, H. Yokoi, M. and Nakahara, N. : Simplified calculation model of vertical air temperature distribution during heating in air-conditioned room : Studies on thermal properties in air-conditioned space (Part 2), Journal of Architecture, Planning and Environmental Engineering (Transactions of AIJ), No. 398, pp. 59-67, 1989. 4 (in Japanese) 伊藤尚寛, 横井睦己, 中原信生 : 温風暖房空間の上下温度分布の簡易計算乇 デル：空調空間の熱的特性に関する研究 第 2 報, 日本建築学会計画系論文報
告集，第 398 号, pp. 59-67, 1989.4

17) Togari, S. Arai, Y. and Miura, K. : Simplified prediction model of vertical air temperature distribution in a large space : Study on a thermal environment design system for large spaces, Part 1, Journal of Architecture, Planning and Environmental Engineering (Transactions of AIJ), No. 427, pp. 9-19, 1991. 9 (in Japanese)

戸河里敏, 荒井良延, 三浦克弘 : 大空間における上下温度分布の予測モデル 一大空間の空調・熱環境計画手法の研究 その 1 , 日本建築学会計画系論文報 告集，第 427 号, pp. 9-19, 1991.9

18) Higashimoto, T. Yamanaka, T. Kotani, H. and Hanano, H. : Temperature and contaminant concentration distribution of dispalacement ventilated rooms with cooled wall : Application of "block model" integrated with thermal plumes to displacement ventilated room, Journal of Environmental Engineering (Transactions of AIJ), No. 571, pp. 47-53, 2003. 9 (in Japanese)

東本丈明, 山中俊夫, 甲谷寿史, 花野弘行 : 冷却面を有寸る置換換気室内の 温度・污染物濃度分布: 熱プルームを組み込んだブロックモデルの適用, 日本 建築学会環境系論文集, 第 571 号, pp. 47-53, 2003.9

19) Sako, H. Higuchi, M. Shibahara, T. Takai, H. Takesako, M. and Ishii, S. : Field measurement of a thermal environment and energy conservation in the office building utilizing night purge system and natural ventilation and hybrid air-conditioning, Technical papers of annual meeting, the SHASE, pp. 1587-1590, 2004. 8 (in Japanese)

迫博司, 樋口祥明, 芝原崇慶, 高井啓明, 竹迫雅史, 石井佐知子 : ナイトパ ージ・自然換気・ハイブリッド空調を導入したオフィスビルにおける 室内 環境実測と省エネルギー効果の検証, 空気調和・衛生工学大会学術講演会論 文集，pp. 1587-1590，2004.8

20) Yamanaka, T. Kotani, H. and Miyamoto, K. : Ventilation Performance of Floor-Supply Air-conditioning System : Part 1-Prediction Model of Vertical Distribution of Pollutant Concentration in Room with Circular Supply Openings, Journal of SHASE, No. 112, pp. 13-21, 2006. 7 (in Japanese)

山中俊夫，甲谷寿史，宮本敬介：床吹出し空調システムの換気性能に関する 研究 第 1 報円形吹出し口の場合における室内污染物濃度の鉛直分布予測手 法,空気調和・衛生工学会論文集, 第 112 号, pp. 13-21, 2006. 7

21) Murakami, S. Kato, S. and Nakagawa, H. : Numerical and experimental study for flow and temperature fields in rooms with horisontal nonisothermal jets, Journal of Architecture, Planning and Environmental Engineering (Transactions of AIJ), No. 423, pp. 11-21, 1991. 5 (in Japanese)

村上周三, 加藤信介, 中川浩之 : 水平非等温噴流を有する室内の流れ場 - 温 度場の数值解析, 日本建築学会計画系論文報告集, 第 423 号, pp. 11-21, 1991. 5

22) Kaji, H. Akanayashi, S. and Sakaguchi, J. : CFD analysis for detached house Study on the ventilation efficiency on constantly ventilated house Part 1, Journal of Environmental Engineering (Transactions of AIJ), Vol. 74, No. 636, pp. 161-168, 2009. 2 (in Japanese)

鍛治紘子, 赤林伸一, 坂口淳: 戸建住宅を対象とした CFD 解析 常時換気 システムが設置された住宅の換気効率に関する研究 その 1 , 日本建築学会 環境系論文集，第 74 巻，第 636 号, pp. 161-168, 2009. 2

23) Kondo, J. Iizuka, S. Yoon, G. Sakai, Y. Sasaki, M. and Okumiya, M. : Estimation of mixing energy loss in an air-conditioned room by a coupled analysis of CFD and HVAC system simulations : Study on energy simulation coupling with CFD for HVAC system Part 2, Journal of Environmental Engineering (Transactions of AIJ), Vol. 77, No. 672, pp. 81-87, 2012. 2 (in Japanese)

近藤順也, 飯塚悟, 尹奎英, 坂井友香, 佐々木美奈, 奥宮正哉 : CFD - 空調 システムシミュレーション連成解析による室内混合損失の推定: CFD と連成 した空調システムシミュレーションに関する研究 第 2 報, 日本建築学会環 境系論文集，第 77 巻，第 672 号, pp. 81-87, 2012. 2

24) Takano, Y. Akabayashi, S. Tominaga, Y. Sakaguchi, J. Honda, M. and Arinami, Y. : Analysis of cross ventilation airflow in and around simple house model considering flow fluctuation:Study on naturally cross-ventilated house using large-eddy simulation(LES) part 1, Journal of Environmental Engineering (Transactions of AIJ), Vol. 80, No. 716, pp. 925-934, 2015. 10 (in Japanese) 
高野康夫, 赤林伸一, 富永禎秀, 坂口淳, 本田美穂, 有波裕貴 : 単純住宅乇 デルを対象とした変動気流場における室内外通風性状の解析： LES(Large-Eddy Simulation)による住宅の自然換気・通風性状に関する研 究 その 1 , 日本建築学会環境系論文集, 第 80 巻, 第 716 号, pp. 925-934, 2015. 10

25) Kobayashi, T. Sugita, K. and Umemiya, N. : A study on semi-displacement ventilation using impinging jet flow - Prediction of vertical temperature distribution using block model based on numerical experiment by cfd, Journal of Environmental Engineering (Transactions of AIJ), Vol. 81, No. 730, pp. 1117-1126, 2016. 12 (in Japanese) 小林知広, 杉田雄希, 梅宮典子 : 床面衝突噴流を用いた準置換換気空調方式 に関する研究－CFD を用いた数值実験に基づくブロックモデルによる室内 鉛直温度分布の予測一，日本建築学会環境系論文集，第 81 巻，第 730 号， pp. 1117-1125, 2016. 12

26) Fukai, K. and Gotoh, S. : A study on utilization of phase change material for creating of indoor thermal environment (part 1), Technical papers of annual meeting, the SHASE, pp. 317-320, 1986. 10 (in Japanese)

深井一夫, 後藤滋 : 室内熱環境形成における潜熱蓄熱材 $(\mathrm{PCM})$ の利用に関す る研究(その 1)：PCM 熱特性の数值モデル化と PCM 蓄熱式床暖房システム の数值シミュレーションへの適用, 空気調和・衛生工学会学術講演会論文集, pp. $317-320$, 1986. 10 


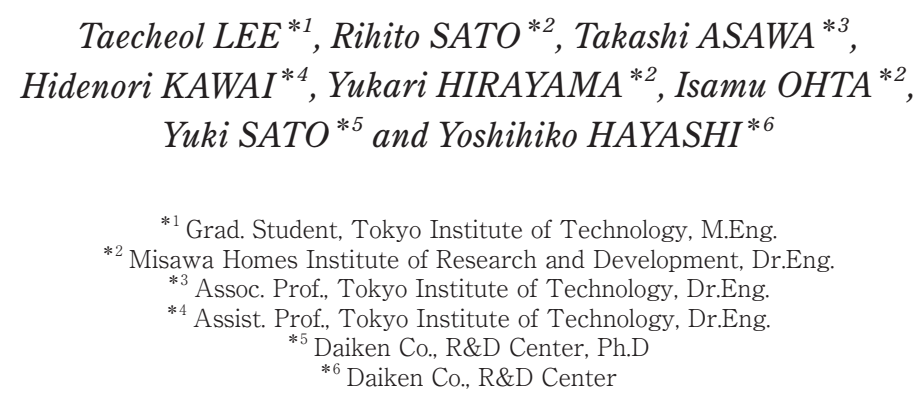

\section{Introduction}

In this paper, we focused on introduction of phase change material(PCM) into a house to secure a cold storage with night natural ventilation. We conducted measurement in order to understand indoor thermal characteristics in a room with night natural ventilation for introducing PCM on the floor of a house to maximize cooling effect. Measurement was mainly conducted for on a room of the full-scale house where it has two openings at floor level. We measured vertical air temperature distribution and inflow wind speed to understand indoor thermal characteristics. And heat flow was also measured on the floor and under the floor to reveal cold storage mechanism.

\section{Categorization}

We categorized measurement results according to weather condition on each day as follows. 1) Day of large air temperature difference between indoor and outdoor $(\Delta \mathrm{T})$ with high inflow wind speed, 2) Day of large $\Delta \mathrm{T}$ with low inflow wind speed, and 3) Day of small $\Delta \mathrm{T}$ with high inflow wind speed.

\section{Measurement summary on indoor thermal characteristics}

Vertical air temperature distribution of indoor was influenced by inflow wind speed and $\Delta \mathrm{T}$. In case that inflow wind speed was lower than $0.1 \mathrm{~m} / \mathrm{s}$, cold air accumulated along the floor was not mixed with the air at upper area of indoor. In case that inflow wind speed was over $0.1 \mathrm{~m} / \mathrm{s}$ and under $0.3 \mathrm{~m} / \mathrm{s}$, inlet air mixed with indoor air. At this time, mixing height was determined by $\Delta \mathrm{T}$ and inflow wind speed. In case that inflow wind speed was over $0.3 \mathrm{~m} / \mathrm{s}$, indoor air was entirely mixed with outdoor air, thus vertical air temperature distribution tended to be disappeared.

\section{Measurement summary on cold storage}

Cold storage tended to be proportional to $\Delta \mathrm{T}$. Cold storage accelerated as the condition of large $\Delta \mathrm{T}$ and low inflow wind speed because cold air accumulated along the floor was not mixed with upper air of indoor. In case that air temperature near the floor was $2^{\circ} \mathrm{C}$ lower than phase change temperature of PCM for solidification, latent cold storage begun to progress. Cold storage ratio of latent heat was averagely $70 \%$, and total cold storage tended to change approximate 1.5 times depending on outdoor air temperature.

\section{Conclusion}

Indoor thermal characteristics and cold storage rate were changed by $\Delta \mathrm{T}$ and inflow wind speed. In some cases, latent cold storage efficiency of PCM on the floor with night natural ventilation was confirmed. In the future, considering the daily life activity of residents, we are going to research passive cooling effect of PCM including the day time. Also, in order to develop a numerical simulation tool for designing a passive cooling house with PCM including a calculation model of vertical air temperature distribution, we will determine the parameter of turbulence diffusion coefficient by CFD simulation. 